\title{
On the Feasible Linkages between Iranian Academic EFL Learners' Emotional Intelligence Level and Their Lexico-semantic Errors in Writing
}

\author{
Parviz Alavinia \\ Urmia University, Iran \\ Email:pevinia2006@yahoo.com \\ Nasim Behyar \\ Maragheh Islamic Azad University, Iran
}

\begin{abstract}
Successive to more than two decades of stringent probes into various aspects of EQ gains, now the field of emotional intelligence enjoys an unparalleled status. In an attempt to address one of the untouched realms relevant to EQ, 100 Iranian academic EFL students were randomly chosen form PNU (Payam-e-Noor University) and Islamic Azad University of Mahabad and Boukan. The purpose of the current study was to find whether the learners' emotional intelligence level significantly correlated with their performance in terms of lexico-semantic errors. The main instrument utilized for data collection was Bar-on's Emotional Quotient Inventory (EQ-i, Bar-on, 1997). For being able to tap the learners' lexico-semantic errors, they were asked to write two short paragraphs. Texts were, then, read through with the aim of identifying the lexico-semantic deviants. In order to cater for reliability concerns, three raters corrected the participants' papers. As the findings of the study helped reveal, the learners' EI level was found to have a significant amount of correlation with lexico-semantic errors of female and male academic EFL students. Nevertheless, gender didn't act as an important determiner of learners' EQ and their lexico-semantic errors. It is also worth noting that all fifteen EQ subscales were found to have sufficient predictive value as to the learners' lexico-semantic errors. It was also fascinating to find that out of the fifteen subscales of EI questionnaire, happiness had the highest predictive value with respect to the learners' lexico-semantic errors.
\end{abstract}

Index Terms-Bar-On's EQ-i, EI, emotional intelligence, EQ, lexico-semantic errors

\section{INTRODUCTION}

The early scholars who contemplated over the notion of intelligence were not psychologists and even educators, but philosophers. The concept of intelligence has witnessed a variety of orientations and reorientations throughout history, from earlier views like Plato's who likened it to "blocks of wax differing in size, hardness, moistness, and purity" (cited in Cianciolo \& Strenberg, 2004, p.1), to more recent ones like Gardner who regarded it as an assortment of intelligences, quite independent of each other, with each intelligence having its own strengths and constraints. Twentieth century was enriched with a number of developments in the field of intelligence. Binet and Simon, for instance, regarded intelligence as "a well-developed judgment skill that children apply to benefit from education" (cited in Cianciolo \& Sternberg, 2004, p. 58).

It was toward the end of the twentieth century that scholars came to pinpoint that it is not only IQ, regarded as a fixed notion, that brings about an individual's achievement, and it was just at this point that Gardner's (1983) revolutionary theory of multiple intelligences and Goleman's (1995) groundbreaking theory of emotional intelligence came to be widely endorsed. Defining emotional intelligence as including "abilities such as being able to motivate oneself and persist in the face of frustration, to control impulses and delay gratification; to regulate one's moods and keep distress from swapping the ability to think; to emphasize and to hope" Daniel Goleman (1995,p.34), the prominent spokesperson for emotional intelligence, held that roughly 80 percent of the variance among people in various forms of success that is unaccounted for by IQ test and similar tests can be explained by other characteristics that constitute emotional intelligence.

Now after more than two decades since its early inception, the concept of emotional intelligence has turned to a commonplace terminology within the modern research community, toward which a plethora of varied (interdisciplinary) investigations have been targeted. In Iran like many other countries, the campaign for scrutinizing the diverse gains resulting from EQ has long been established. Yet, only in the recent years has emotional intelligence been probed so widely, particularly on the part of educational practitioners (e.g. Rouhani, 2007, 2008; Pishghadam, 2007, 2009; and Alavinia, 2010, 2011a/b). 


\section{A. Statement of the Problem and Research Questions}

A fleeting glimpse through the literature on EQ reveals the fact that an exhaustive amount of work has, particularly recently, been appropriated to gauging myriad potential gains germane to possessing high levels of emotional intelligence. Yet, one of the domains toward which scant attention seems to have been paid is the viable influence of EI on learners' efficiency and proficiency to write. It is supposed that the multiplicity of skills involved in writing might be the principal factor that contributes to its overall difficulty. Thus, faced with the alleged paucity of research in this rather intact area, it seems plausible to go about a through-going scrutiny through the feasible go-togetherness between EI, on the one hand and learners' success in writing, on the other. Put more clearly, the chief purpose of the current study is finding out whether EI can act as a predictor of learners' writing proficiency, particularly in terms of lexicosemantic errors. Provided that the results of this study confirm the strong relationship between lexico-semantic errors and the learner's EI, attempts should be made to put an ever-increasing emphasis on the individuals' emotional terrains in educational arena.

To be able to investigate the postulations set forth in the current study, the following research questions were formulated:

1. Is there a significant relationship between the academic Iranian EFL learners' EQ level and the amount of lexicosemantic errors committed by them?

2. Is there any significant relationship between gender of the academic Iranian EFL learners and their level of Emotional Intelligence?

3. Is there any relationship between gender of the academic Iranian EFL learners and their performance in terms of lexico-semantic errors?

\section{B. Significance of the Study}

Although some scholars still believe that IQ plays a domineering role in learners' success, others believe in EI and its superseding influence on learners' achievement. Mayor and Salovy among others suggest that learners with high EI can be considered as those with high success in their courses (cited in Nazem, 2008). Though a multitude of investigations, thus far, have grappled with diverse facets of EQ and its disparate implications and repercussions in an individual's academic/social life, there are still some perspectives which have either gone unnoticed or been paid meager heed. One such partially intact area of research might be the viable effect of possessing a high level of EQ on learners' writing proficiency, in general and their committing lexico-semantic errors, in particular. Thus, the current probe might be said to be significant in that it is mainly driven by unique causes, which, to the researchers' best knowledge, haven't received due heed in the existing literature on emotional intelligence and its myriad utilities.

Accordingly, the result of the current are thought to prove beneficial for all the stakeholders of (higher) education system. Curriculum developers and syllabus designers can also take certain measures on the basis of the gained results, particularly in terms of the implementation of fruitful pedagogic tasks to account for learners' emotional side. It is also hoped that the current study might help the instructors include the appropriate strategies relevant to the principles of EI in their minute-by-minute activities in the classroom. If the results of the present study assert that EI is liable to act as a predictor of learners' lexico-semantic errors, it can aid the learners reduce their errors of writings. English language learners can also be aware of the forgotten power of their emotional side and try to adapt it in their way to success in all university courses.

\section{Background on the Concept of Intelligence}

In line with Spearman's view put forth in 1920s, intelligence was a "combination of a general factor (g), which is available to an individual to the same degree for all intellectual acts, as well as several specific factors which vary in strength from one act to another" (p.32). From the time scholars have tried to write and think about intelligence, they have substantially concentrated on the cognitive aspects. However, according to Cherniss (2000), there are some who bring non-cognitive aspects into focus. Wechsler (1958) defines intelligence as "the aggregate or global capacity of the individual to act purposefully, to think rationally, and to deal effectively with his environment" (Cherniss, 2000, p.2). Nonetheless, in an attempt to stand opposed to the traditional pillars of the concept of intelligence, Gardner (1983) asserts that instead of considering it as a unitary concept, it should be seen as a multiplex of mental capabilities.

Moreover, Sternberg proposes the triarchic theory of intelligence, which consists of three main elements: metacomponents, performance components, and knowledge acquisition. Metacomponents are the cognitive skills used in decision making. Performance components deal with actual operation. Knowledge acquisitions are the processes used in acquisition knowledge (cited in Williams \& Burden, 1997).

Among other researchers concerned with the development of the notion of intelligence, Salovey and Mayer are the ones who play the major role in the development of a more personal-affective type of intelligence. It was in 1990 when the term EI was first coined by these scholars. Having been aware of the research conducted by Salovey and Mayer, Goleman, then a science writer in TIME magazine, authored his first book 'Emotional Intelligence' in 1995, in which he offered the proof that besides cognitive factors of intelligence, emotional and social factors are also of great significance. Mayer and Salovey suggest that EI consists of the ability to receive correctly and express emotions; the ability to reach and produce emotions; the ability to understand emotion; and the ability to organize emotions to foster both emotion and intelligence (cited in Mortiboys, 2005). 
Finally, Sparrow and Knight (2006, p.28) present the ABC triangle for EI which is very effective as follows: The ' $\mathrm{ABC}$ ' triangle is comprised of affects (a pretentious medical name for feeling for emotion), behavior (a grander word for doing) and cognition (a pretentious psychological name for thinking). According to Sparrow and Knight (2006) "thinking and feeling are broadly inputs and doing generally an output. So to emphasize that doing is the result of feeling and/or thinking, we put feeling and thinking together on a level, with a similar relation to doing" (p.29).

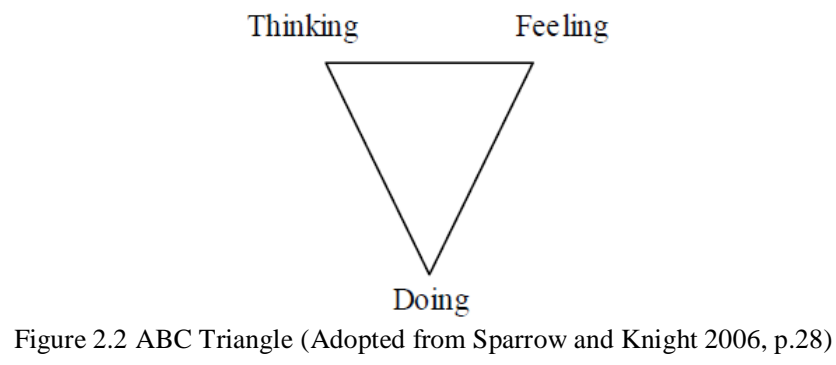

\section{Measures of Emotional Intelligence}

The history of theorizing on what the construct of emotional intelligence would look like has always proceeded hand in hand with another line of endeavor aiming at the provision of several operationalized measurement scales approaching the concept of emotional intelligence from a number of different angles. Though literature is replete with several attempts aimed at scrutinizing the construct of emotional intelligence, not all such rough and ready enterprises are worth giving in-depth deliberation in the current study.

Overall, in line with Mayer, Caruso, and Salovey (2000), three branches of emotional intelligence tests exist alternatively being referred to as ability, self-report, and observer or informant rating scales. The sample measures they then put forth as the major archetypes of each scale are: 1) their own renowned test (Mayer, Salovey, \& Caruso, 1997/1999) widely known as MEIS (Multifactor Emotional Intelligence Scale) which is ubiquitously cited as the paramount epitome of ability scales, 2) Bar-On's (1997) EQ-i and Cooper's (1996/1997) EQ-Map which are stated as the principal types of self-report measures, and 3) Boyatzis, Goleman, and Hay/McBer's (1999) Emotional Competence Inventory (ECI) that is known as the best example of third group of scales drawing mainly on observer (informant) responses. As the main EQ scale used in the present study is Bar-On's Emotional Quotient Inventory (widely known as EQ-i), in the ensuing section a laconic account will be provided of a number of elemental features of this typical selfreport measure of emotional intelligence, and each of its components will be briefly defined and elucidated.

Bar-On's EQ-i

First designed as an experimental scale for measuring the so-called emotional and social competence in the early 1980s (Bar-On, 1985, 1988), Emotional Quotient Inventory (EQ-i) was ultimately disseminated as an invaluable and highly pervasive measure of emotional intelligence in 1997. Though a plethora of EI scales had been publicized and promulgated prior to the appearance of Bar-On's (1997a) seminal work, EQ-i can be considered sui generis in that it is referred to as the primary EI test which is published by a psychological center. Furthermore, the additional factor that differentiates between Bar-On's scale and its other counterparts is the distinct nature of EQ-i which is widely known as a self report measure (Bar-On, 2000).

The self-report test of emotional intelligence designed by Bar-On (1997b), is after submitting a firm measurement of "an array of noncognitive capabilities, competencies, and skills that influence one's ability to succeed in coping with environmental demands and pressures" (p.14). Its unabridged version is composed of 133 items normally being allotted something around forty minutes to fulfill and is said to be apposite to the age of seventeen and above. This scale is composed of five sections and fifteen separate subsections as follows:

1. Intrapersonal, consisting of five subcategories of emotional self awareness, assertiveness, self-regard, selfactualization, and independence

2. Interpersonal, encompassing the three sub-skills of empathy, interpersonal relationship, and social responsibility

3. Stress management, having as its subparts the two so-called categories of stress tolerance and impulse control

4. Adaptability, comprising the three divisions of problem solving, reality testing, and flexibility

5. General mood, entailing the two subscales of happiness and optimism.

Below are succinct delineations for each of the 15 subscales of EQ-i (based on Bar-On, 2000, pp.365-366):

Emotional Self-Awareness (ES) is the ability to recognize and understand one's emotions; Assertiveness $(A S)$ is the ability to express feelings, beliefs, and thoughts, and to defend one's rights in a nondestructive manner; Self-Regard (SR) is the ability to be aware of, understand, accept, and respect oneself; Self-Actualization (SA) is the ability to realize one's potential and to do what one wants to do, enjoy doing, and can do; Independence (IN) is the ability to be self-directed and self-controlled in one's thinking and actions and to be free of emotional dependency; Empathy (EM) is the ability to be aware of, understand, and appreciate the feelings of others; Social Responsibility (RE) is the ability to demonstrate oneself as a cooperative, contributing, and constructive member of one's social group; Interpersonal Relationship (IR) is the ability to establish and maintain mutually satisfying relationships that are characterized by emotional closeness, intimacy, and by giving and receiving affection; Reality Testing $(R T)$ is the ability to access the correspondence 
between what is internally and subjectively experienced and what externally and objectively exists; Flexibility (FL) is the ability to adjust one's feelings, thoughts, and behavior to changing situations and conditions; Problem Solving (PS) is the ability to identify and define personal and social problems as well as to generate and implement potentially effective solutions; Stress Tolerance (ST) is the ability to withstand adverse events, stressful situations, and strong emotions without "falling apart" by actively and positively coping with stress; Impulse Control (IC) is the ability to resist or delay an impulse, drive, or temptation to act, and to control one's emotions; Optimism (OP) is the ability "to look at the brighter side of life" and to maintain a positive attitude, even in the face of adversity; Happiness (HA) is the ability to feel satisfied with one's life, to enjoy oneself and others, and to have fun and express positive emotions.

\section{Empirical Studies on $\mathbf{E Q}$}

As the studies on various aspects of EI are quite varied and extensive, a brief mention is made here of some of the most eye-catching ones. In so doing, the researchers will refer to the previous body of research under two separate headings of EQ and learning, and EQ and teaching.

\section{EQ and Learning}

To mention just a few studies on the implications of EQ for learning, Naglieri and Bornstein (2003) probed the would-be correlation between administration of tests related to intelligence and learners' achievement, Rouhani (2007) investigated how a cognitive/affective-based reading course which focuses on literature affects the construct of EI, Pishghadam (2009) worked toward a quantitative analysis of the relationship between EI and foreign language learning, and Alavinia (2010) scrutinized the viability of enhancing EFL learners' emotional intelligence through the implementation of fuzzy thinking and emotional engineering.

Furthermore, some other researchers working in the realm of performance-relevant aspects of EI are Rooy and Viswesvaran (2004) who examine the relationship between EI and performance outcomes, Stubbs (2005) who searches the linkages between EI and group performance, Hader (2006) who reports significant correlation between emotional intelligence and both cognitive and social task performance, and Seal (2006) who investigates the association between emotional competency and performance outcomes.

\section{EQ and Teaching}

Gains in teaching due to emotional intelligence is the next intriguing perspective which is addressed in Haskett's (2002) study of the relationship between emotional intelligence and teaching success in higher education, Phillips' (2005) investigation of the bonds between emotional intelligence and effective teaching, Drew's (2006) scrutiny of the liaisons between emotional intelligence and student teacher performance, as well as in Justice and Espinoza's (2007) probe into the linkages between emotional intelligence and beginning teacher candidates. In view of the fact that successful marriage is among the major indicators of life success/satisfaction, research on this alternative area is to be discussed in the ensuing segment.

\section{Methodology}

\section{A. Participants}

A total of 100 Iranian EFL students (both male and female) studying at PNU and Islamic Azad Universities of Mohabad and Boukan participated in the present study. The partakers were junior and senior undergraduate students majoring in TEFL and English Language Translation. Table 1 and 2 illustrate the specifications of the study participants in terms of both field of study and gender, and Figure 1 illustrates the gender distribution of partakers in a more cogent manner. As can be seen, 60 percent of respondents were female and 40 percent were male.

TABLE 1

FREQUENCY OF PARTICIPANTS BASED ON FIELD OF STUDY AND GENDER

\begin{tabular}{|l|l|l|l|}
\hline \multirow{2}{*}{ Field of study } & \multicolumn{2}{|l|}{ Gender } & \multirow{2}{*}{ Total } \\
\cline { 2 - 3 } & Male & Female & \\
\hline TEFL & 30 & 40 & 70 \\
\hline Translation & 10 & 20 & 30 \\
\hline Total & 40 & 60 & 100 \\
\hline
\end{tabular}

TABLE 2

GENDER DISTRIBUTION OF PARTICIPANTS

\begin{tabular}{|l|l|l|}
\hline Gender & Frequency & Frequency percent \\
\hline Male & 40 & $\% 40$ \\
\hline Female & 60 & $\% 60$ \\
\hline Total & 100 & $\% 100$ \\
\hline
\end{tabular}




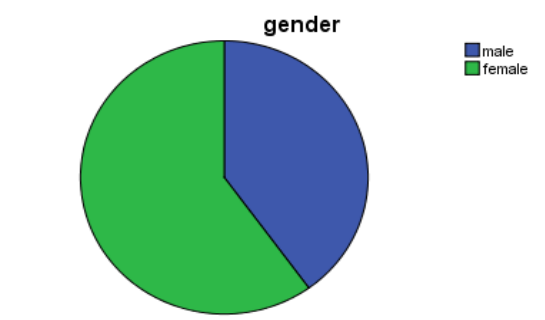

Figure 1 Gender Distribution Chart

\section{B. Instrumentation}

The main instrument used in this study was Bar-on's Emotional Quotient Inventory (EQ-i, Bar-on, 1997). Though the original version of the test included 133 questions, later revisions applied to the test by Bar-On himself (1997a, 1997b) reduced its size to a considerable degree, so that the modified version of the test comprised only 117 questions. Furthermore, through later amendments, the size of the domestically standardized instrument was reduced through eradicating the questions which had been rendered either irrelevant or inappropriate to Iranian context by Samouei (2003), who first introduced the test for domestic implementation. Thus, what was utilized as the main source of data collection for the current research was this very reduced form which encompassed 90 questions arranged in 15 separate sections, i.e. the so called subscales of Emotional Self-Awareness, Assertiveness, Self-Regard, Self-Actualization, Independence, Empathy, Social Responsibility, Interpersonal Relationship, Reality Testing, Flexibility, Problem Solving, Stress Tolerance, Impulse Control, Optimism, and Happiness.

The result of the endeavors aimed at domestic standardization of the test, handed satisfactory validity and reliability indices (As Samouei (2003) reported the calculated Cronbach's alpha equaled 0.93, and the reliability index gained through odd-even, split-half method was 0.88). This latter test was conducted on some 500 students (aging 18 to 40) from a number of different majors studying at several domestic universities including Isfahan and Khorasegan Universities. To carry out the experiment, Samouei (2003) had employed the 117-item version of the test which through later analysis was adjusted to include only 90 questions. In an alternative attempt, Karami (2005) reports of a similar study with a group of participants studying at Tehran University, at the end of which the researcher came up with the identical figure of 0.73 for both methods of test-retest and Cronbach's alpha, and hence a satisfactory level of reliability. Yet, opposed to Samouei's experiment, this alternative study had employed the very original version of the test including 133 questions.

\section{Design and Procedure}

The current study was ex-post facto in nature and mainly followed a correlational design. Successive to the administration of Bar-On's EQ-i, some guidelines and tips were provided for the learners on how to fill the questionnaire. Later on, the learners were asked to write two paragraphs regarding their courses and the university in which they were studying. The paragraphs were written by the subjects in their classrooms under the supervision of one of the researchers. Next, the paragraphs were read through with the aim of identifying the lexico-semantic deviants in them. The basis for establishing the deviants was the contrast made with the Standard English of educated speakers. All the deviations were traced to four linguistic sources: collocation, generalization, similarity, and duplication, which are further subdivided into seven lexico-semantic relation deviants (see Table 3 for a more lucid grasp of the lexicosemantic categories applied in the current study). Furthermore, to come up with more objective and reliable results the learners' written texts were corrected by three scorers, and all the lexico-semantic errors were identified for each and every individual learner. The total scale for the given scores was set at 20. A total of 85 lexico-semantic errors were identified in the data. The tabulations below highlight the number of occurrences of each of the error categories and their overall percentages. Subsequent to data collection, Spearman's correlation and Pearson product moment correlation were estimated to gauge the viable effect of learners' EQ level on their committing lexico-semantic errors.

\section{Collocation Errors}

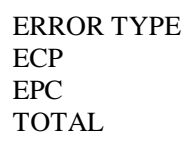

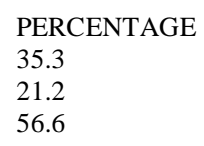$$
56.6
$$

\section{Generalization Errors}

\author{
ERROR TYPE \\ EOG \\ TOTAL
}

$\begin{array}{ll}\text { OCCURRENCE } & \text { PERCENTAGE } \\ 3 & 3.5 \\ 3 & 3.5\end{array}$

\section{Similarity Errors}




$\begin{array}{lll}\text { ERROR TYPE } & \text { OCCURRENCE } & \text { PERCENTAGE } \\ \text { MSE } & 16 & 18.8 \\ \text { SSE } & 7 & 8.2 \\ \text { TOTAL } & 23 & 27.0\end{array}$

\section{Duplication Errors}

$\begin{array}{lll}\text { ERROR TYPE } & \text { OCCURRENCE } & \text { PERCENTAGE } \\ \text { MDE } & 6 & 7.0 \\ \text { WDE } & 5 & 5.9 \\ \text { TOTAL } & 11 & 12.9\end{array}$

As the figures presented above reveal Collocation Errors are predominant in the data (they account for $56.6 \%$ of the total Lexico-Semantic Relation Errors). Next to Collocation Errors are Similarity Errors that account for $27.0 \%$ of the entire errors. The other categories of errors, i.e. Duplication and Generalization Errors account for $12.9 \%$ and $3.5 \%$ of the total deviations, respectively.

TABLE 3

LEXICO-SEMANTIC RELATION PROBLEMS

\begin{tabular}{|c|c|c|c|c|c|c|}
\hline \multicolumn{2}{|c|}{ COLLOCATION } & \multirow{2}{*}{$\begin{array}{l}\text { GENERALISATION } \\
\text { Error of } \\
\text { Generalization }\end{array}$} & \multicolumn{2}{|c|}{ SIMILARITY } & \multicolumn{2}{|l|}{ DUPLICATION } \\
\hline $\begin{array}{l}\text { Error of } \\
\text { Collocation of } \\
\text { Prepositions }\end{array}$ & $\begin{array}{l}\text { Error of } \\
\text { Probable } \\
\text { Collocations }\end{array}$ & & $\begin{array}{l}\text { Meaning } \\
\text { Similarity } \\
\text { Error }\end{array}$ & $\begin{array}{l}\text { Sound } \\
\text { Similarity } \\
\text { Error }\end{array}$ & $\begin{array}{l}\text { Meaning } \\
\text { Duplication Error }\end{array}$ & $\begin{array}{l}\text { Word } \\
\text { Duplication } \\
\text { Error }\end{array}$ \\
\hline ECP & EPC & EOG & MSE & SSE & MDE & WDE \\
\hline
\end{tabular}

\section{RESULTS}

\section{A. Analysis of Research Question One}

1. Is there a significant relationship between the Academic Iranian EFL learners' EQ level and the amount of lexicosemantic errors committed by them?

TABLE 4

SIMPLE CORRELATION COEFFICIENTS BETWEEN EMOTIONAL INTELLIGENCE AND LEXICO-SEMANTIC ERRORS

\begin{tabular}{|l|l|l|l|l|}
\hline $\begin{array}{l}\text { Total Sample } \\
(\mathbf{n})\end{array}$ & $\begin{array}{l}\text { Level of Significance } \\
(p)\end{array}$ & $\begin{array}{l}\text { The Correlation } \\
\text { Coefficient }(r)\end{array}$ & $\begin{array}{l}\text { Statistical Indicators } \\
\text { Predictive Variable }\end{array}$ & \begin{tabular}{l} 
Criterion Variable \\
\hline 100
\end{tabular} \\
\hline
\end{tabular}

As seen in the above table there is a significant Correlation between emotional intelligence and lexico-semantic errors $(r=0.911 \& p=0.000)$. Thus, the null hypothesis relevant to the first research question is rejected and evidence is found in favor of the go-togetherness between learners' EQ and the degree of lexico-semantic errors committed by them. Yet, to come up with more cogent upshots, further analysis was done to find the would-be bonds between each single subscale of EQ and the learners' lexico-semantic errors. Thus, in the following fifteen tables the statistical data relevant to the correlation between EQ subscales and learners' lexico-semantic errors have been illustrated.

\section{1). Emotional Self-Awareness}

TABLE 5

SIMPLE CORRELATION COEFFICIENT BETWEEN SELF-AWARENESS AND LEXICO-SEMANTIC ERRORS

\begin{tabular}{|l|l|l|l|l|}
\hline $\begin{array}{l}\text { Total Sample } \\
(\mathbf{n})\end{array}$ & $\begin{array}{l}\text { Level of Significance } \\
(p)\end{array}$ & $\begin{array}{l}\text { The Correlation } \\
\text { Coefficient }(r)\end{array}$ & $\begin{array}{l}\text { Statistical Indicators } \\
\text { Predictive Variable }\end{array}$ \\
\hline 100 & 0.000 & 0.809 & Self-Awareness & Lexico-Semantic Errors \\
\hline
\end{tabular}

As seen in the above table, level of significance is less than 0.05 . Therefore, it can be contended that a significant relationship holds between students' lexico-semantic errors and their Emorional Self-Awareness $(p=0.000 \& r=0.809$ ).

\section{2). Assertiveness}

TABLE 6

SIMPLE CORRELATION COEFFICIENT BETWEEN ASSERTIVENESS AND LEXICO-SEMANTIC ERRORS

\begin{tabular}{|l|l|l|l|l|}
\hline $\begin{array}{l}\text { Total Sample } \\
(\mathbf{n})\end{array}$ & $\begin{array}{l}\text { Level of Significance } \\
(p)\end{array}$ & $\begin{array}{l}\text { The Correlation } \\
\text { Coefficient }(r)\end{array}$ & $\begin{array}{l}\text { Statistical Indicators } \\
\text { Predictive Variable }\end{array}$ & \begin{tabular}{l} 
Criterion Variable \\
\hline 100
\end{tabular} \\
\hline
\end{tabular}

As can be seen in Table 6, the level of significance is less than 0.05 . Thus, there is a significant relationship between students' lexico-semantic errors and their Assertiveness ( $p=0.000 \& r=0.708)$.

3). Empathy 
TABLE 7

SIMPLE CORRELATION COEFFICIENT BETWEEN EMPATHY AND LEXICO-SEMANTIC ERRORS

\begin{tabular}{|l|l|l|l|l|}
\hline $\begin{array}{l}\text { Total Sample } \\
(\mathbf{n})\end{array}$ & $\begin{array}{l}\text { Level of Significance } \\
(p)\end{array}$ & $\begin{array}{l}\text { The Correlation } \\
\text { Coefficient }(r)\end{array}$ & $\begin{array}{l}\text { Statistical Indicators } \\
\text { Predictive Variable }\end{array}$ & \begin{tabular}{l} 
Criterion Variable \\
\hline 100
\end{tabular} \\
\hline
\end{tabular}

In line with the information presented in Table 7, a significant correlation exists between students' lexico-semantic errors and their Empathy $(p=0.000 \& r=0.710)$.

\section{4). Social Responsibility}

TABLE 8

SIMPLE CORRELATION COEFFICIENT BETWEEN SOCIAL RESPONSIBILITY AND LEXICO-SEMANTIC ERRORS

\begin{tabular}{|l|l|l|l|l|}
\hline $\begin{array}{l}\text { Total Sample } \\
(\mathbf{n})\end{array}$ & $\begin{array}{l}\text { Level of Significance } \\
(p)\end{array}$ & $\begin{array}{l}\text { The Correlation } \\
\text { Coefficient }(r)\end{array}$ & $\begin{array}{l}\text { Statistical Indicators } \\
\text { Predictive Variable }\end{array}$ & \begin{tabular}{l} 
Criterion Variable \\
\hline 100
\end{tabular} \\
\hline
\end{tabular}

The findings reported in Table 8 point to another instance of significant correlation between the learners' lexicosemantic errors and their Social Responsibility $(p=0.000 \& r=0.691)$.

5). Flexibility

TABLE 9

SIMPLE CORRELATION COEFFICIENT BETWEEN FLEXIBILITY AND LEXICO-SEMANTIC ERRORS

\begin{tabular}{|l|l|l|l|l|}
\hline $\begin{array}{l}\text { Total Sample } \\
(\mathbf{n})\end{array}$ & $\begin{array}{l}\text { Level of Significance } \\
(p)\end{array}$ & $\begin{array}{l}\text { The Correlation } \\
\text { Coefficient }(r)\end{array}$ & $\begin{array}{l}\text { Statistical Indicators } \\
\text { Predictive Variable }\end{array}$ & \begin{tabular}{l} 
Criterion Variable \\
\hline 100
\end{tabular} \\
\hline
\end{tabular}

On account of the data depicted in Table 9, a significant correlation can be said to be at work between students' lexico-semantic errors and their Flexibility $(p=0.000 \& r=0.677)$.

\section{6). Impulse Control}

TABLE 10

SIMPLE CORRELATION COEFFICIENT BETWEEN IMPULSE CONTROL AND LEXICO-SEMANTIC ERRORS

\begin{tabular}{|l|l|l|l|l|}
\hline $\begin{array}{l}\text { Total Sample } \\
(\mathbf{n})\end{array}$ & $\begin{array}{l}\text { Level of Significance } \\
(p)\end{array}$ & $\begin{array}{l}\text { The Correlation } \\
\text { Coefficient }(r)\end{array}$ & $\begin{array}{l}\text { Statistical Indicators } \\
\text { Predictive Variable }\end{array}$ & \begin{tabular}{l} 
Criterion Variable \\
\hline 100
\end{tabular} \\
\hline
\end{tabular}

As is seen in the above table, a significant relationship holds between students' lexico-semantic errors and their Impulse Control $(p=0.000 \& r=0.608)$.

7). Self-Regard

TABLE 11

SIMPLE CORRELATION COEFFICIENT BETWEEN SELF-REGARD AND LEXICO-SEMANTIC ERRORS

\begin{tabular}{|l|l|l|l|l|}
\hline $\begin{array}{l}\text { Total Sample } \\
(\mathbf{n})\end{array}$ & $\begin{array}{l}\text { Level of Significance } \\
(p)\end{array}$ & $\begin{array}{l}\text { The Correlation } \\
\text { Coefficient }(r)\end{array}$ & $\begin{array}{l}\text { Statistical Indicators } \\
\text { Predictive Variable }\end{array}$ & \begin{tabular}{l} 
Criterion Variable \\
\hline 100
\end{tabular} \\
\hline
\end{tabular}

Drawing on the data illustrated in Table 11, it can be claimed that there is a significant relationship between students' lexico-semantic errors and their Self-Regard ( $p=0.000 \& r=0.816)$.

8). Optimism

TABLE 12

SIMPLE CORRELATION COEFFICIENT BETWEEN OPTIMISM AND LEXICO-SEMANTIC ERRORS

\begin{tabular}{|c|c|c|c|c|}
\hline $\begin{array}{l}\text { Total Sample } \\
\text { (n) }\end{array}$ & $\begin{array}{l}\text { Level of Significance } \\
(p)\end{array}$ & $\begin{array}{l}\text { The Correlation } \\
\text { Coefficient }(r)\end{array}$ & $\begin{array}{l}\text { Statistical Indicators } \\
\text { Predictive Variable }\end{array}$ & Criterion Variable \\
\hline 100 & 0.000 & 0.792 & Optimism & Lexico-Semantic Errors \\
\hline
\end{tabular}

As Table 12 shows, optimism, the other subscale of Bar-On's EQ-i, significantly correlates with the learners' lexicosemantic errors $(p=0.000 \& r=0.792)$.

9). Interpersonal Relationship

TABLE 13

SIMPLE CORRELATION COEFFICIENT BETWEEN INTERPERSONAL RELATIONSHIP AND LEXICO-SEMANTIC ERRORS

\begin{tabular}{|l|l|l|l|l|}
\hline $\begin{array}{l}\text { Total Sample } \\
(\mathbf{n})\end{array}$ & $\begin{array}{l}\text { Level of Significance } \\
(p)\end{array}$ & $\begin{array}{l}\text { The Correlation } \\
\text { Coefficient }(r)\end{array}$ & $\begin{array}{l}\text { Statistical Indicators } \\
\text { Predictive Variable }\end{array}$ & \begin{tabular}{l} 
Criterion Variable \\
\hline 100
\end{tabular} \\
\hline
\end{tabular}

Based on what is presented in Table 13, the relationship between students' lexico-semantic errors and their Interpersonal Relationship is again significant $(p=0.000 \& r=0.707)$.

10). Reality Testing 
TABLE 14

SIMPLE CORRELATION COEFFICIENT BETWEEN REALITY TESTING AND LEXICO-SEMANTIC ERRORS

\begin{tabular}{|l|l|l|l|l|}
\hline $\begin{array}{l}\text { Total Sample } \\
(\mathbf{n})\end{array}$ & $\begin{array}{l}\text { Level of Significance } \\
(p)\end{array}$ & $\begin{array}{l}\text { The Correlation } \\
\text { Coefficient }(r)\end{array}$ & $\begin{array}{l}\text { Statistical Indicators } \\
\text { Predictive Variable }\end{array}$ & \begin{tabular}{l} 
Criterion Variable \\
\hline 100
\end{tabular} \\
\hline
\end{tabular}

As Table 14 reveals, another significant correlation holds between students' lexico-semantic errors and their Reality Testing. ( $p=0.000 \& r=0.758)$.

\section{1). Self-Actualization}

TABLE 15

SIMPLE CORRELATION COEFFICIENT BETWEEN SELF-ACTUALIZATION AND LEXICO-SEMANTIC ERRORS

\begin{tabular}{|l|l|l|l|l|}
\hline $\begin{array}{l}\text { Total Sample } \\
(\mathbf{n})\end{array}$ & $\begin{array}{l}\text { Level of Significance } \\
(p)\end{array}$ & $\begin{array}{l}\text { The Correlation } \\
\text { Coefficient }(r)\end{array}$ & $\begin{array}{l}\text { Statistical Indicators } \\
\text { Predictive Variable }\end{array}$ & \begin{tabular}{l} 
Criterion Variable \\
\hline 100
\end{tabular} \\
\hline
\end{tabular}

Self-Actualization also correlates significantly with the learners' lexico-semantic errors (based on the data illustrated in Table $15, p=0.000 \& r=0.826)$.

12). Stress Tolerance

TABLE 16

SIMPLE CORRELATION COEFFICIENT BETWEEN STRESS TOLERANCE AND LEXICO-SEMANTIC ERRORS

\begin{tabular}{|l|l|l|l|l|}
\hline $\begin{array}{l}\text { Total Sample } \\
(\mathbf{n})\end{array}$ & $\begin{array}{l}\text { Level of Significance } \\
(p)\end{array}$ & $\begin{array}{l}\text { The Correlation } \\
\text { Coefficient }(r)\end{array}$ & $\begin{array}{l}\text { Statistical Indicators } \\
\text { Predictive Variable }\end{array}$ & \begin{tabular}{l} 
Criterion Variable \\
\hline 100
\end{tabular} \\
\hline
\end{tabular}

On the basis of the findings presented in Table 12, once again a significant correlation is encountered between students' lexico-semantic errors and their Stress Tolerance $(p=0.000 \& r=0.769)$.

13). Happiness

TABLE 17

SIMPLE CORRELATION COEFFICIENT BETWEEN HAPPINESS AND LEXICO-SEMANTIC ERRORS

\begin{tabular}{|l|l|l|l|l|}
\hline $\begin{array}{l}\text { Total Sample } \\
(\mathbf{n})\end{array}$ & $\begin{array}{l}\text { Level of Significance } \\
(p)\end{array}$ & $\begin{array}{l}\text { The Correlation } \\
\text { Coefficient }(r)\end{array}$ & $\begin{array}{l}\text { Statistical Indicators } \\
\text { Predictive Variable }\end{array}$ & \begin{tabular}{l} 
Criterion Variable \\
\hline 100
\end{tabular} \\
\hline
\end{tabular}

As Table 17 depicts, the subscale of Happiness, too, correlates significantly with the learners' lexico-semantic errors $(p=0.000 \& r=0.836)$.

14). Problem Solving

TABLE 18

SIMPLE CORRELATION COEFFICIENT BETWEEN PROBLEM SOLVING AND LEXICO-SEMANTIC ERRORS

\begin{tabular}{|l|l|l|l|l|}
\hline $\begin{array}{l}\text { Total Sample } \\
(\mathbf{n})\end{array}$ & $\begin{array}{l}\text { Level of Significance } \\
(p)\end{array}$ & $\begin{array}{l}\text { The Correlation } \\
\text { Coefficient } \quad(r)\end{array}$ & $\begin{array}{l}\text { Statistical Indicators } \\
\text { Predictive Variable }\end{array}$ & \begin{tabular}{l} 
Criterion Variable \\
\hline 100
\end{tabular} \\
\hline
\end{tabular}

According to Table 18, another instance of significant correlation is witnessed with regard to the relationship between students' lexico-semantic errors and their Problem Solving ability $(p=0.000 \& r=0.716)$.

\section{5). Independence}

TABLE 19

SIMPLE CORRELATION COEFFICIENT BETWEEN INDEPENDENCE AND LEXICO-SEMANTIC ERRORS

\begin{tabular}{|c|c|c|c|c|}
\hline $\begin{array}{l}\text { Total Sample } \\
\text { (n) }\end{array}$ & $\begin{array}{l}\text { Level of Significance } \\
(p)\end{array}$ & $\begin{array}{l}\text { The Correlation } \\
\text { Coefficient }(r)\end{array}$ & $\begin{array}{l}\text { Statistical Indicators } \\
\text { Predictive Variable }\end{array}$ & Criterion Variable \\
\hline 100 & 0.000 & 0.636 & Independence & Lexico-Semantic Errors \\
\hline
\end{tabular}

Faced with the significant correlation ( $p=0.000 \& r=0.636)$ holding between the learners' Independence and lexico-semantic errors (see Table 19), the researchers come to the conclusion that all subscales of Bar-On's EQ-i correlate significantly with the learners' lexico-semantic errors, that is to say individuals who possess higher levels of emotional intelligence are found to commit fewer errors of lexico-semantic type.

\section{B. Analysis of Research Question Two}

2. Is there any significant relationship between gender of the academic Iranian EFL learners and their level of Emotional Intelligence? 
TABLE 20

SIMPLE CORRELATION COEFFICIENT BETWEEN GENDER AND LEXICO-SEMANTIC ERRORS

\begin{tabular}{|l|l|l|l|l|}
\hline $\begin{array}{l}\text { Total Sample } \\
(\mathbf{n})\end{array}$ & $\begin{array}{l}\text { Level of Significance } \\
(p)\end{array}$ & $\begin{array}{l}\text { The Correlation } \\
\text { Coefficient }(r)\end{array}$ & $\begin{array}{l}\text { Statistical Indicators } \\
\text { Predictive Variable }\end{array}$ & \begin{tabular}{l} 
Criterion Variable \\
\hline 100
\end{tabular} \\
\hline
\end{tabular}

As seen in Table 20, there is no significant correlation between the participants' gender and their performance in terms of lexico- semantic errors $(r=-0.038 \& p=0.378)$.

\section{Analysis of Research Question Three}

3. Is there any relationship between gender of the academic Iranian EFL learners and their performance in terms of lexico-semantic errors?

TABLE 21

SIMPLE CORRELATION COEFFICIENT BETWEEN GENDER AND LEARNERS' DEGREE OF EMOTIONAL INTELLIGENCE

\begin{tabular}{|l|l|l|l|l|}
\hline $\begin{array}{l}\text { Total Sample } \\
(\mathbf{n})\end{array}$ & $\begin{array}{l}\text { Level of Significance } \\
(p)\end{array}$ & $\begin{array}{l}\text { The Correlation } \\
\text { Coefficient }(r)\end{array}$ & $\begin{array}{l}\text { Statistical Indicators } \\
\text { Predictive Variable }\end{array}$ & \begin{tabular}{l} 
Criterion Variable \\
\hline 100
\end{tabular} \\
\hline
\end{tabular}

Finally, drawing on the information presented in Table 21, it can be concluded that no significant correlation holds between the participants gender and the degree of their Emotional Intelligence $(r=-0.083 \& p=0.207)$.

\section{DisCUSSION AND CONCLUSION}

The purpose of the current study was to find whether EI correlates significantly with the learners' lexico-semantic errors. The statistical analysis of the data led the researchers to conclude that EI could have predictive value to predict the lexico-semantic errors among academic Iranian EFL learners. Nonetheless, as the findings of the study revealed, gender didn't act as an important determiner of learners' EQ and their lexico-semantic errors. Another noticeable piece of finding in the present study was that all fifteen subscales of Bar-On's EQ-i significantly correlated with lexicosemantic errors. It was also interesting to find that out of the fifteen subscales of EI questionnaire, happiness had higher predictive value to apropos learners' lexico-semantic errors. The findings of the current study might be said to be in line with Barchard (2003), who maintained that EI predicts the academic success, and Zahrakar (2007) who found that there is a positive relationship between components of EI and academic achievement.

Further, the findings of the current research reveal that collocation errors are predominant (accounting for 56.5\% of the total lexico-semantic errors). The reason for this might be traced to improper mastery of lexical sense relations. This aspect of lexical studies is often neglected in ESL/EFL classroom. As a result, the writers cannot define boundaries that separate lexical items. Thus, it can be concluded that teachers should teach lexical sense relations and should emphasize collocations, especially the types that learners have difficulties with (for instance, the flawed categories with the highest occurrence in the present study). Pupils might also be encouraged to read a lot of literature written in English, since collocations are better acquired through reading.

Finally, as emotional intelligence was found to be of significance with respect to the individuals' lexico-semantic errors, the implication might be that teachers' endeavors aimed at enhancing learners' emotional intelligence level (as is discussed in Alavinia, 2011, a/b), is likely to lead to the individuals' improved performance in terms of lexico-semantic errors.

\section{REFERENCES}

[1] Alavinia, P. (2010). The Viability of Enhancing EFL Learners' Emotional Intelligence Directed by Fuzzy Thinking and Emotional Engineering. Unpublished PH.D. Dissertation, Allameh Tabataba'i University, Tehran, Iran.

[2] Alavinia, P. (2011a). Emotional Engineering through the Application of Fuzzy Logic: Enhancing Emotional Intelligence by Raising Awareness of Emotions. Germany: VDM Verlag.

[3] Alavinia, P. (2011b). Toward the Refutation of Herrnstein and Murray's Maxims: Is (Emotoinal) Intelligence Acquirable and Modifiable through Scooling? Germany: Lambert Academic Publishing.

[4] Barchard, K. A. (2003). Does emotional intelligence assist in the prediction of academic success? Educational and Psychological Measurement, 63, 840-858

[5] Bar-On, R. (1985). The development of an operational concept of psychological well-being. Unpublished doctoral dissertation (first draft), Rhodes University, South Africa.

[6] Bar-On, R. (1988). The development of a concept of psychological well-being. Unpublished doctoral dissertation (final draft), Rhodes University, South Africa.

[7] Bar-On, R. (1997a). The Emotional Quotient Inventory (EQ-i): A test of emotional intelligence. Toronto: Multi-Health Systems.

[8] Bar-On, R. (1997b). BarOn Emotional Quotient Inventory (EQ-i): Technical manual. Toronto: Multi-Health Systems.

[9] Bar-On, R. (2000). Emotional and social intelligence: Insights from the emotional quotient inventory. In R. Bar-On \& J.D.A. Parker (Eds.), The handbook of emotional intelligence: Theory, development, assessment, and application at home, school, and in the workplace (pp.363-388). San Francisco, CA: Jossey-Bass. 
[10] Boyatzis, R.E., Goleman, D., \& Rhee, K.S. (2000). Clustering competence in emotional intelligence: Insights from the emotional competence inventory. In R. Bar-On \& J.D.A. Parker (Eds.), The handbook of emotional intelligence: Theory, development, assessment, and application at home, school, and in the workplace (pp.343-362). San Francisco, CA: Jossey-Bass.

[11] Cherniss C. (2000). Emotional intelligence: what it is and why it matters. Paper presented at the Annual Meeting of the society for Industrial and Organizational Psychology, New Orleans: LA.

[12] Cianciolo, A. T., \& Strenberg, R.J. (2004). A brief history of intelligence. Malden, MA: Blackwell.

[13] Cooper, R.K. (1996/1997). EQ Map. San Francisco: AIT and Essi Systems.

[14] Drew, T.L. (2006). The relationship between emotional intelligence and student teacher performance. Unpublished doctoral dissertation, University of Nebraska, Lincoln, Nebraska.

[15] Gardner, H. (1983). Frames of mind: The theory of multiple intelligences. New York: Basic Books.

[16] Goleman, D. (1995). Emotional intelligence: Why it can matter more than IQ. New York: Bantam Books.

[17] Hader, E.M. (2006). Emotional intelligence and its relationship to cognitive and social task requirements. Unpublished doctoral dissertation, Alliant International University, San Diego.

[18] Haskett, R.A. (2002). Emotional intelligence and teaching success in higher education. Unpublished doctoral dissertation, Indiana University.

[19] Justice, M. \& Espinoza, S. (2007). Emotional intelligence and beginning teacher candidates. Education, 127 (4), $456-461$.

[20] Karami, A. (2005). Houshe hayajani (Emotional Intelligence). Tehran: Markaze Nashre Ravansanji.

[21] Mayer, J.D., Salovey, P., \& Caruso, D.R. (1997). The Emotional IQ Test [CD-Rom]. Needham, MA: Virtual Knowledge.

[22] Mayer, J.D., Salovey, P., \& Caruso, D.R. (1999a). MSCEIT Item Booklet (Research Version 1.1.) Toronto, Canada: MultiHealth Systems.

[23] Mayer, J.D., Salovey, P., \& Caruso, D.R. (1999b). Working Manual for the MSCEIT Research Version 1.1. Manuscript in preparation, available from Multi-Health Systems, Toronto, Canada.

[24] Mayer, J.D., Salovey, P., \& Caruso, D.R. (2000). Emotional intelligence as zeitgeist, as personality, and as a mental ability. In R. Bar-On \& J.D.A. Parker (Eds.), The handbook of emotional intelligence: Theory, development, assessment, and application at home, school, and in the workplace (pp. 92-117). San Francisco, CA: Jossey-Bass.

[25] Mortiboys, P. (2005). Teaching with emotional intelligence. London: Rutledge.

[26] Naglieri, J. A, Bornstein, B. T. (2003). Intelligence and achievement: Just how correlated are they? Journal of Psychoeducational Assessment, 21(3), 244-260.

[27] Nazem, F. (2008). Emotional intelligence of the managers in Islamic Azad University. The Journal of Modern Thoughts in Education, 3(2), 11-21.

[28] Phillips, M. (2005). An analysis of emotional intelligence and faculty qualities necessary for success in a nontraditional classroom setting. Unpublished doctoral dissertation, Walden University.

[29] Pishghadam, Reza (2007). On the influence of emotional and verbal intelligences on second language learning. Unpublished doctoral dissertation, Allameh Tabataba'i University, Tehran.

[30] Pishghadam, R. (2009). Emotional and verbal intelligences in language learning. Iranian Journal of language Studies, 3(1), 4364.

[31] Rooy, D.L.V., \& Viswesvaran, C. (2004). Emotional intelligence: A meta-analytic investigation of predictive validity and nomological net. Journal of Vocational Behavior, 65, 71-95.

[32] Rouhani, A (2007). EQ beyond IQ: Facts and fictions, literature, emotional intelligence. Paper presented at the Fourth TELLSI Conference, Shiraz, Iran.

[33] Rouhani, A. (2008). An investigation into emotional intelligence, foreign language anxiety and empathy through a cognitiveaffective course in an EFL context. Linguistik online, 34(2), 41-57. Retrieved July 15, 2009 from http://www.linguistik online.de/34_08/rouhani.html

[34] Salovey, P., \& Mayer, J.D. (1989/1990). Emotional intelligence. Imagination, Cognition, and Personality, 9, 185-211.

[35] Samouei, R. (2003). Azmoune houshe hayajani (Bar-On's EQ-i). Tehran: Moasseseye Tahghighatie Olume Raftarie Sina.

[36] Seal, C.R. (2006). Emotional intelligence: An exploratory study of emotional ability as a moderator between emotional competency and performance outcomes. Unpublished doctoral dissertation, The George Washington University, Washington D C.

[37] Sparrow, T., \& Knight, A (2006). Applied EI: The importance of attitudes in developing emotional intelligence. England: Jossey-Bass.

[38] Stubbs, E.C. (2005). Emotional intelligence competencies in the team and team leader: A multi-level examination of the impact of emotional intelligence on group performance. Unpublished doctoral dissertation, Case Western Reserve University.

[39] Wechsler, D. (1958). The measurement and appraisal of adult intelligence. (4th ed.). Baltimore, MD: The Williams \& Wilkins Company.

[40] Williams, M., \& Burden, R. L. (1997). Psychology for language teachers: A social constructivist approach. Cambridge: Cambridge University Press.

[41] Zahrakar, K. (2007). The relationship between emotional intelligence and academic performance in Islamic Azad University. The Journal of Applied Psychology, 2(5), 89-98.

Parviz Alavinia was born in Urmia, 1978. He got his PhD in TEFL/TESOL from Allameh Tabataba'i University in Tehran, Iran, 2010, his MA (in the same major) from The University for Teacher Training in Tehran, Iran, 2004, and his BA degree from Urmia University, Urmia, Iran, 2001.

$\mathrm{He}$ is currently involved as a full-time assistant professor and staff member at Urmia University. Two of his recent publications are listed below: 
Alavinia, P. (2011a). Emotional Engineering through the Application of Fuzzy Logic: Enhancing Emotional Intelligence by Raising Awareness of Emotions. Germany: VDM Verlag.

Alavinia, P. (2011b). Toward the Refutation of Herrnstein and Murray's Maxims: Is (Emotoinal) Intelligence Acquirable and Modifiable through Scooling? Germany: Lambert Academic Publishing.

His main areas of interests include psycholinguistics, philosophy of language, critical discourse analysis and particularly emotional intelligence. He used to be TELLSI member from 2004 to 2008, and a member of the Linguistic Society of Iran from 2003 till 2006, and has been L-test member since 2003.

Nasim Behyar was born in Mohabad, 1984. She holds an MA in TEFL from Maragheh Islamic Azad University, and got her BA in TEFL from Islamic Azad University (Tabriz branch), Iran, 2007.

She is mainly interested in psycholinguistics and in particular emotional intelligence. 